\title{
PEDAGOGY
}

\section{Building Effective Blended Learning In Teacher Training}

\author{
M. Antoshkiv, O. Trebenko \\ National Pedagogical Dragomanov University (Kyiv, Ukraine) \\ Corresponding author.m.s.antoshkiv@npu.edu.ua, trebenko@npu.edu.ua \\ Paper received 10.09.20; Accepted for publication 24.09.20.
}

\section{https://doi.org/10.31174/SEND-PP2020-236VIII94-01}

\begin{abstract}
The article describes how to build effective Blended Learning in mathematics teacher training. Research has been taken at the Faculty of Physics and Mathematics of the National Pedagogical Dragomanov University since 2011. The results obtained convince in the prospect of using Blended Learning and its relevance to the psychological characteristics, capabilities and needs of the digital generation students.
\end{abstract}

Keywords: Blended Learning, Algebra and Number Theory course, Generation “Z”, Digital Generation, Teacher Training.

Introduction. Information technologies in the last 20-30 years have become leading in all spheres of human life. Today's society spends much of its time ina virtual environment: social networks, cloud and other network services. The Internet has long been used not only for work but also for entertainment, communication, recreation. For people born until the mid-1990s, this immersion into the Internet has been gradual; hence they are often referred to as digital immigrants [1]. For a generation of young people growing up and educated during the rapid informatization and computerization of society and the widespread use of gadgets, IT has already been commonplace since childhood. The cognitive and emotional spheres of this generation have evolved under the strong influence of information technology, so the psychological capabilities and needs of these people are significantly different from those of previous generations. Therefore, this generation is called digital, and its representatives are called digital natives [1].

Digital natives are most likely to have a different kind of learning experience than previous generations had at school and university. To teach members of the digital generation effectively, it's important to take into account how they interact with the world and learn.

According to the results of "The Digital Natives as Learners: Technology Use Patterns and Approaches to Learning" [2] members of the digital generation (DG) are accustomed to use only some certain limited types of technologies, despite the fact that they grew up in the era of rapid IT development.Therefore, the use of IT in education itself is not a guarantee for an increase in the efficiency of the learning process. Teacher's role is now being transformed, becoming even more critical than before. Currently, the teacher is simultaneously a guide, tutor, facilitator and expert of the educational process [2]. It is he who can support the potential of the digital generation, teach them how to learn, using both innovative and traditional tools.

Taking into account all above mentioned, we conclude that the question of finding ways to organise the learning process of digital students effectively is relevant to the professional preparation at all levels and in all areas of education. However, it is the future teachers who should study exceptionally innovatively. Since a good teacher is extremely sensitive to children and attentive to what they like and need to do their best in learning, he should be able to implement innovative technologies to support his pupils.
One of such the most promising educational technologies is Blended Learning becoming now more and more popular in Ukraine, in particular due to the Covid-19 pandemic. However, the experience of using elements of Blended Learning in Ukrainian educational institutions has a much longer history. This is spelt out further in the paper, which outlines the Blended Learning experience at the National Pedagogical University.

The objective of this paper is to cover the experience of implementing Blended Learning in mathematics teacher training at the National Pedagogical Dragomanov University and outline directions for further research. This paper however focuses on the elements of Blended Learning that have confirmed their effectiveness and omits the detailed quantitative data of questionnaires and tests. For a detailed review of the experiments see other authors' publications.

Materials and methods. Summarizing the results of investigations [3]-[4], we may outline the psychological characteristics, educational needs of members of the DG and effective teaching approaches as follows (Table 1).

Education in the 21st century should be focused on these needs of the younger generation. Using old methods in teaching will not bring the expected result.

An experiment on implementing Blended Learning of Algebra and Number Theory carried out at the Faculty of Physics and Mathematics of the National Pedagogical Dragomanov University showed that it is Blended Learning that best meets the needs of the psychological characteristics of the DG[5]. Note that under Blended Learning we mean 'purposeful process of acquiring knowledge, acquisition of skills and abilities, mastering the methods of cognitive activity by the subjects of learning and the development of his creative abilities based on integrated and systematic use of traditional, innovative pedagogical technologies and ICT in order to improve the quality of education' [6].

Results and its discussion. The research on the development and implementation of Blended Learning of Algebra and Number Theory Course for students of mathematical specialities has been carried out at the Physics and Mathematics Faculty of the National Pedagogical Dragomanov University since 2011. As of 2020, several elements have been singled out allowing to adapt the educational process to the needs and capabilities of modern students, as well as to increase the efficiency of learning material and motivation to study. Consider theminmore detail.

Open online course (OCATh) 
Open Online Course on Algebra and Theory was initially introduced in 2015 to organize distance learning during energy-saving holidays, which took place in Ukraine in winter 2014-2015 [7]. The course lasted for 4 weeks. One topic has been studied for one week. Since then, OCATh has become a part of Algebra and Number Theory Course.

To study the topic students should follow the next algorithm (Picture 1).

Table 1

\begin{tabular}{|c|c|c|}
\hline n & Psychological characteristics & Educational needs / Teaching approaches \\
\hline 1 & $\begin{array}{l}\text { Fragmented thinking, indifference to details, problems with } \\
\text { concentration leading to weak and short-term memory }\end{array}$ & $\begin{array}{l}\text {-Structured educational content, offering portioned presentation } \\
\text { of information, without long lectures and long reads; } \\
\text {-Involving in every stage of the learning process and using } \\
\text { stimulating creative activities for full engagement; } \\
\text {-Activities for memory development and learning not to } \\
\text { remember but to find and critically evaluate the necessary } \\
\text { information }\end{array}$ \\
\hline 2 & Visual perception of information & High-quality and end-to-end visualization of educational material \\
\hline 3 & $\begin{array}{l}\text { Addiction to social networks and virtual communication, love to } \\
\text { publicity, problems with subordination }\end{array}$ & $\begin{array}{l}\text { Using social networks, tasks that involve publicity, cultivate } \\
\text { corporate ethics }\end{array}$ \\
\hline 4 & $\begin{array}{l}\text { Undeveloped mechanisms of self-regulation (self-control, self- } \\
\text { organization, self-education etc.) }\end{array}$ & Learning to self-control, self-organize, self-educate \\
\hline 5 & $\begin{array}{l}\text { High personal anxiety, vulnerability, reflection, weak resistance to } \\
\text { stress }\end{array}$ & Tutor's psychological support \\
\hline 6 & Tendency to use templates in any case & $\begin{array}{l}\text { Detailed step-by-step algorithms breaking down tasks into small } \\
\text { parts and explaining each step }\end{array}$ \\
\hline 7 & $\begin{array}{l}\text { No desire to gain independence, no global life goals, information } \\
\text { overload, maladaptation to life }\end{array}$ & $\begin{array}{l}\text { Improving critical thinking abilities, assistance in finding life } \\
\text { landmarks }\end{array}$ \\
\hline 8 & $\begin{array}{l}\text { Individualism, a habit to virtual communication, difficulties with } \\
\text { offline and team collaboration (DG prefer to perform individual tasks } \\
\text { to contribute to a team initiative rather than completing the entire task } \\
\text { as a group) }\end{array}$ & Engaging team building activities \\
\hline 9 & Expecting immediate feedback / rewards & $\begin{array}{l}\text { Organizing instant educational communication via messengers or } \\
\text { social networks }\end{array}$ \\
\hline
\end{tabular}

1. Learning/revising theoretical material. To study the theoretical material students are offered different types of educational content: video lectures, digital text materials, reference block diagrams etc. The choice of the form of presenting theory depends on an amount of theoretical material given in the classroom. If the theory was considered in a lecture, then students just repeat it through reference schemes. Either they study it independently through video lectures. In both cases specially designed support schemes help them to systematize knowledge and recall the most important points.

It should be emphasised that the experiment conducted in 2013-2014 confirmed the hypothesis that video lectures are capable of providing the same level of primary assimilation of material as the classroom ones [8].

2. Passing a self-test on each topic.To check if the theoretical material is mastered students should pass a selftest. The correct detailed answers and overview of possible mistakes are given in audio format.

3. Solving practical tasks. Each type of problems is treated in the following way:

3.1) answering questions that help them to understand the condition of the task, update the necessary theoretical material and find the method for solving the task;

3.2) going through a video explaining how to solve tasks of this type;

3.3) formulating steps to solve the task (schematic algorithm);

3.4) solving tasks of the type considered;

3.5) passing the test that includes tasks of the type considered.

4. Passing a final test on the topic. At the end of the topic, students have a final test checking the level of acquiring of learning material and the need for follow-up revision.

5. Doing an individual task. Within the course, the offline student-student and student-teacher interaction is organized both through the Moodle forum and through the educational community in the social network.

\section{Picture1}

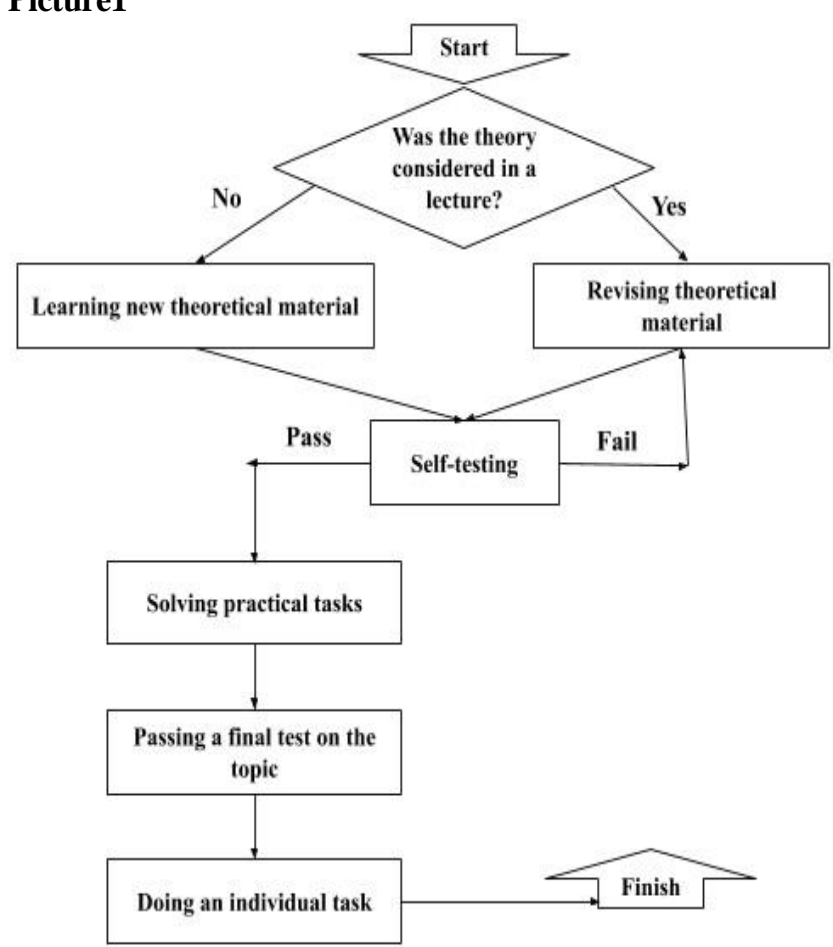

The student's personal assistant is a tutor - a counselor responsible for the psychological support of the course. He can guide participants in solving their problems connected with the task performance and working out learning materials. Tutor:

- helps a student to orient in the educational trajectory;

- provides answers to organizational questions; 
- facilitates the work on tasks, helps to understand the content of tasks;

- $\quad$ offers additional materials;

- $\quad$ acts as an intermediary between a teacher and a student, promotes more sincere communication;

- supports students in reflecting on their study.

Senior students, who have once studied this discipline, may be involved as tutors. In this case, the barrier between teacher and students is minimal, it helps to share experiences with each other and communicate more easily.

Through the course, students get the opportunity not only to acquire new knowledge, but also to develop their selfeducating and self-controlling skills, to learn how to critically evaluate the results of their activities.

Team Project Video Tournament

To improve teamwork skills and project activities and to study the material more effectively, students take part in a video project team tournament. Tournament participants form micro groups (3-5 students); each micro group is given a complex task. To find the answer to the task, students need to complete several intermediate exercises and film an explanation of the entire solving process. Students assign responsibilities for solving intermediate tasks and video producing within the micro group.

Students' videos can be classic video tutorials as well as videos with their scenario. By a classic video tutorial, we mean a video when a student explains how to solve the problem writing on the class board or the paper. The example of the video with an unusual scenario is a full short-length film [9] about a kidnapped princess; to save her, one needs to solve a tournament task. At the end of the tournament, there is usually a classroom project defence, during which each micro group presents the results of their work, and the teacher evaluates the videos by detailed criteria and gives explanation to the assessments. Such activity takes into account the students' love for publicity, and, at the same time, promotes the development of pedagogical skills and forms the ability to communicate in the group successfully.

Social networks

As most digital students communicate and collaborate in various virtual communities, the use of social networks to organize educational communication helps to enhance extracurricular cooperation, to build instant communication between students and a teacher. Social networking is the resource that is most commonly used by modern students; hence communication through networks is familiar and comfortable for the majority of them. In addition to the instant communication and the ability to provide psychological support for learning, the use of social networks contributes to establishing sincere contact between the teacher and students and helps them understand each other better. The use of social networks enables successful educational cooperation and discussion online, sharing opinions, impressions and ideas, improves the emotional climate in the group.

Since the functionality of main social networks is about the same today, the choice usually depends on what network is used by a majority of students of the particular group.

Creative competitions

In order to increase students' motivation to study and master the profession, it is appropriate to hold various creative competitions periodically. For example, in 2014-2015, as part of an open online course in algebra and number theory, a mathematical creativity competition was offered.
Under the terms of the competition, it was necessary to produce any creative product (a drawing, a poem, a song, a handcrafted item) about mathematics. Such an initiative aroused great interest and enthusiasm among students. The resulting works were original and varied. One participant even demonstrated the ability to do hairstyles in the form of geometric objects.

Another example of a creative competition was a contest of sketches on the history of number theory, held in the fall of 2017-2018. According to the competition rules, students in micro groups had to prepare an electronic newspaper for one of the selected topics related to the history of number theory. The materials in the newspaper were not just abstract messages. The participants had to imagine themselves to be contemporaries to some historical period of development in the theory of numbers, to "interview" the world-famous mathematicians, to write "hot" news about the most important discoveries. Students took such an initiative with curiosity and excitement. In the end, they presented full and very original electronic editions.

The main advantage of the described creative competitions is the increase of students' motivation to study, but there are a number of other advantages. Such activities offer students opportunities for self-expression, development of pedagogical and teamwork skills. As it was noticed, an informal approach to learning helps to assimilate study materials more consciously.

Learning-to-learn video

Since 2018, instructive materials explaining how to study Number Theory Course (and even any mathematical discipline) are offered to students both in video and text format.

One of the characteristics of the DG students is the need for psychological support during their studies and the availability of a tutor who can guide and advise.

Most of these questions can be answered in the form of a short video.

For example, many students in the field of mathematics are anxious about the need to study the proofs of mathematical statements. They consider proofs to be cumbersome, complex and absolutely unnecessary for further work. However, proofing itself is a valuable mathematical tool. Learning proofs develops logical thinking, teaches reasoning, and helps to form a coherent picture of the interrelationships between mathematical objects. The ability to prove mathematical statements is incredibly valuable to both future mathematicians and educators. This can be communicated to students through a learning-to-learn video where the virtual teacher uses computer animation to explain the importance of the proofs, the fundamental necessity to study it, and some life-hacks facilitating the process of handling the proofs.

Similar videos can be created to answer any other contradictory questions that students experience considerable difficulty. As it has appeared, such content was a good emotional support for students.

Virtual self-examiner

One of the most challenging tasks of the course is the adequate preparation of students for the colloquiums and exams. Usually, students postpone it to the last moment. That's why they do not have the opportunity to calmly, consistently and consciously review all course materials they have learned.

Revision and self-examination should be regular, while the time before the exam should be for a final comprehension of 
the learning material, not a hasty study of all that has been missed.

To support and facilitate students in the preparation for exams and colloquiums, a virtual self-examiner was developed and implemented. A virtual self-examiner is a special tool located on the distance course site (Moodle platform). It offers learning-to-learn videos, self-testing exercises and questions, a proof trainer, an exam tasks constructor. The exam task constructor produces a list of randomly generated exam tasks having the same structure as exam one.

To provide students feedback on their attitude to each of the Blended Learning elements mentioned, a survey was conducted indicating that Blended Learning intensifies an educational process, enhances students' motivation to study and self-control. An additional argument for using BL elements developed is the same and sometimes a higher level of students' learning achievements while the ability to think independently and succeed in teamwork turns to be more sophisticated and the learning process itself is becoming emotionally comfortable.

Conclusions. To sum up, the implementation of Blended Learning elements discussed above in the mathematics teacher training program at the National Pedagogical Dragomanov University has shown them to be efficient to match the psychological characteristics and educational needs of DG students, develop students' soft skills and increase their motivation to lifelong learning. It was established that a student becomes an active co-author of the lessons, thereby developing their self-education, self-control and team collaboration skills, increasing motivation for learning and its effectiveness. It is also important that the training is becoming more personalized.

These findings suggested the development and implementation of the new course in the curriculum 'Blended Learning Technology in Teaching Mathematics', aiming to foster students' ideas about Blended Learning technology, its planning and implementation in teaching mathematics at schools and universities, was developed. Since the first class of 2019 has left positive feedback on the relevance of the course, this fall of 2020, the second group of students is mastering the discipline. Details will be covered in the next publication.

We hope that our research will be helpful in solving the difficulty of organizing Blended Learning in teacher training in the time of quarantine. Marc Prensky. - Режим доступу: https://www.marcprensky.com /writing/Prensky\%20-\%20Digital\%20Natives,\%20Digital \%20Immigrants\%20-\%20Part1.pdf(дата звернення 08.09.2020).

2. Penny Thompson. The digital natives as learners: Technology use patterns and approaches to learning [Електронний pecypc] / Penny Thompson. - Режим доступу: https://www.researchgate.net/publication/257171683_The_digita 1_natives_as_learners_Technology_use_patterns_and_approache s_to_learning (дата звернення 08.09.2020).

3. Чичинська О.В. Психологічні особливості представників z покоління [Е. ресурс]/О.В.Чичинська. - Режим доступу: 10/ (дата звернення 08.09.2020).

4. Подік I.I. Студенти Z: особливості та перспективи [Е. peсурc]/I.I.Подік. - Режим доступу:http://www.ndifp.nusta.edu.ua/report/publication/ 20171124094943.PDF (дата звернення 08.09.2020).

5. Антошків М. С. Врахування психологічних особливостей студентів цифрового покоління шляхом організації змішаного навчання// Фізико-математична освіта: науковий
1. Marc Prensky. Digital Natives, Digital Immigrants [E. pecypc] / https://journal.kdpu.edu.ua/psychology/article/download/3734/34 журнал. Вип. 1 (15) / Сумський державний педагогічний

\section{NCIES}

університет імені А.С. Макаренка, Фізико-математичний факультет редкол.: О.В. Семеніхіна (гол.ред.) [та ін.]. - Суми: [СумДПУ ім. А.С. Макаренка], 2018. - С. 128-131.

6. Триус Ю.В. Комбіноване навчання як інноваційна освітня технологія у вищій школі / Ю.В. Триус, І.В. Герасименко // Теорія та методика електронного навчання: збірник наукових праць. Випуск III. - Кривий Ріг: Видавничий відділ НметАУ. -2012. - C. 299-308

7. Антошків М. С., Требенко О. О. Відкритий онлайн-курс як ефективний засіб організації самостійної роботи студентів в навчанні вищої алгебри. / М. С. Антошків, О. О. Требенко // Науковий часопис НПУ імені М. П. Драгоманова. Серія 3. Фізика і математика у вищій і середній школі. - 2015. - Вип. 15. - C. 3-13.

8. Антошків М. С. Можливості використання відеолекцій для інтенсифікації навчання вищої алгебри /М. С. Антошків // Студентські фізико-математичні етюди. - 2013. - № 12. - Том 1. - С. $127-136$

9. Командний турнір відеопроектів з алгебри і теорії чисел [Е. pecypc]. - Режим доступу: https://youtu.be/Wh3-SXCaepk (дата звернення 08.09.2020).

\section{REFERENCES}

3. Chychynska OV (2019) Psy`xologichni osobly`vosti predstavny ${ }^{\circ}$ kiv $\mathrm{z}$ pokolinnya [Psychological features of the representatives of the $\mathrm{Z}$ generation] (electronic journal). Available at: https://journal.kdpu.edu.ua/psychology/ article/download/3734/3410/ (accessed 8 September 2020).

4. Podik II (2017) Studenty` Z: osobly`vosti ta perspekty`vy $[\mathrm{Z}$ students: features and prospects] (electronic journal). Available at: http://www.ndi-fp.nusta.edu.ua/report/publication/ 20171124094943.PDF (accessed 8 September 2020).

5. Antoshkiv MS (2018) Vraxuvannya psy`xologichny`x osobly`vostej studentiv cy`frovogo pokolinnya shlyaxom organizaciyi zmishanogo navchannya [Taking account of psychological features of digital generation students over the organization of Blended Learning]. Fizyko-Matematychna Osvita: naukovy`j zhurnal [Physical and mathematical education: scientific journal], vol. 1 (15), pp. 128-131.

6. Try`us YuV (2012) Kombinovane navchannya yak innovacijna osvitnya texnologiya u vy`shhij shkoli [Blended Learning as an innovative educational technology in high education]. Teoriya ta metody`ka elektronnogo navchannya: zbirny`k naukovy`x pracz`
[Theory and methods of e-learning: a collection of scientific papers], vol. 3, pp. 299-308.

7. Antoshkiv MS, Trebenko OO (2015) Vidkry`ty`j onlajn-kurs yak efekty`vny`j zasib organizaciyi samostijnoyi roboty` studentiv $v$ navchanni vy`shhoyi algebry` [Open online course as an effective means to organize students' independent work in teaching Higher Algebra]. Naukovy`j chasopy`s NPU imeni M. P. Dragomanova. Seriya 3. Fizy`ka i matematy`ka u vy`shhij i serednij shkoli [Scientific journal of NPDU. Series 3. Physics and Mathematics in High School], vol. 15, pp. 3-13.

8. Antoshkiv MS (2013) Mozhly`vosti vy`kory`stannya videolekcij dlya intensy`fikaciyi navchannya vy`shhoyi algebry` [Possibilities of using video lectures to intensify the teaching Higher Algebra]. Students'ki fizy`ko-matematy`chni etyudy'[Students' Physical and Mathematical sketches], vol.12. pp. 127-136.

9. Komandnyy turnir videoproektiv z alhebry i teoriyi chysel [Team tournament of video projects on Algebra and Number Theory] (electronic resourse). Available at: https://youtu.be/Wh3SXCaepk (accessed 8 September 2020). 